\begin{abstract}
Iranica
Abstracta Iranica Revue bibliographique pour le domaine irano-aryen

Volume 34-35-36 | 2017

Comptes rendus des publications de 2011-2013
\end{abstract}

\title{
Maria Giulia Amadasi Guzzo. Sidon et ses sanctuaires
}

\section{Astrid Nunn}

\section{OpenEdition}

\section{Journals}

Édition électronique

URL : http://journals.openedition.org/abstractairanica/41599

DOI : 10.4000/abstractairanica.41599

ISSN : 1961-960X

Éditeur :

CNRS (UMR 7528 Mondes iraniens et indiens), Éditions de l'IFRI

\section{Référence électronique}

Astrid Nunn, « Maria Giulia Amadasi Guzzo. Sidon et ses sanctuaires », Abstracta Iranica [En ligne], Volume 34-35-36 | 2017, document 48, mis en ligne le 15 juillet 2016, consulté le 30 septembre 2020. URL : http://journals.openedition.org/abstractairanica/41599; DOI : https://doi.org/10.4000/ abstractairanica.41599

Ce document a été généré automatiquement le 30 septembre 2020.

Tous droits réservés 


\title{
Maria Giulia Amadasi Guzzo. Sidon et ses sanctuaires
}

\author{
Astrid Nunn
}

\section{RÉFÉRENCE}

Maria Giulia Amadasi Guzzo. «Sidon et ses sanctuaires ». RA, 106, 2012, p. 5-18.

1 Les volumes de la RA 106 et 107 (2012 et 2013) sont dédiés à Paolo Matthiae qui, par la découverte des archives d'Ebla, a considérablement enrichi l'assyriologie. L'article de M. G. Amadasi Guzzo est délibérément archéologique et traite de l'architecture sacrée construite par les rois de la dynastie d'Echmunazar en se basant sur les inscriptions de cette cité.

2 Selon l'inscription sur son sarcophage, Echmunazar II a bâti plusieurs temples : deux ou trois temples d'Astarté sis dans différents quartiers de Sidon et dédiés à différents aspects de cette déesse, le temple de Baal et le temple d'Echmun. Bod'achtart, petit fils d'Echmunazar I, souverain très actif, soutenu par les souverains perses à une époque visiblement prospère, a construit le temple d'Echmun de la source YDL(L) et celui de «Sidon des Champs» qui correspond au podium II. Reste le ŠRN d'Astarté sur lequel beaucoup d'encre a déjà coulé. S'agit-il d'un étendard, d'un sanctuaire privé, d'une terrasse ou d'une enceinte? Quelle qu'en soit la signification, il souligne l'importance du culte d'Astarté. 


\section{AUTEURS}

\section{ASTRID NUNN}

Université de Munich 